\title{
Architectural Paint Research and the Archaeology of Buildings
}

\author{
Phillipa McDonnell, University of Lincoln
}

\begin{abstract}
Architectural Paint Research (APR) is the archaeological study of interior and exterior applied decoration. Over time, applied layers of paint and other decorative finishes build-up on the surface of a built structure, encapsulating microscopic deposits of material evidence. This evidence can be used to inform the phase dating of a structure, or illuminate the historic

function of a space. It can challenge preconceived ideas of how specific areas were decorated, and track the changes in aesthetics over time. It can identify when architects' ideologies have been balanced by practical considerations. It can provide an insight into the intangible and ephemeral atmosphere that decoration gives to a room. Finally, it can examine the dirt trapped between layers of decoration and thus categorize the physical environmental conditions that surrounded a building at varying points in its history. Although used in the commercial heritage and conservation sectors, Architectural Paint Research is almost completely unknown to building archaeologists. This article aims to introduce APR to a new audience, and argues that is an invaluable tool in the archaeological interpretation of buildings.

Keywords

architecture; conservation; buildings archaeology; paint; wallpaper; decoration; material culture; decorative surfaces; interior design; environment
\end{abstract}

In the last fifty years the study of historic buildings has developed from an antiquarian study, primarily concerned with the development of churches, to a more sophisticated archaeological approach to a range of structures, including domestic, civic and industrial buildings. The emergence of this distinctive form of archaeology has been driven by a requirement to identify those in need of statutory protection, as well as the need to understand and record structures before their conservation or restoration. Techniques have been developed to identify and to phase modifications in the fabric, which have revealed the complex structural history of many buildings. Almost all historic buildings have undergone significant modification, which may include the extension and demolition of part of the structure, as well as changes in the internal spaces. Understanding the sequence of changes 
often requires careful analysis of the fabric, seeking a series of clues to work towards an interpretation which explains a series of initially inexplicable features.

The theoretical and methodological framework surrounding this approach to buildings has grown rapidly over the last few decades. Key texts such as Morris (2000), Rodwell (2005), Wood (1994), and Historic England (2016) have aided the practical undertaking of describing, assessing and interpreting standing structures from an archeological standpoint, whilst theoretical approaches have been bolstered by publications including Samson (1990), Locock (1994), Leach (1997), and Johnson (2010. Previous discussions (Ferris 1989; Meeson 1989; Smith 1989; Bold 1990; Ferris 1991) have emphasised that recording a building is not so much a process of just observing and systematically noting what is visible, but of recognizing the features deemed to be of significance. It is a process of active enquiry in which the researcher seeks a better interpretation by critical engagement with the evidence of the building. This form of recording of buildings is the equivalent of the process in dirt archaeology described as 'interpretation at the trowel's edge' (Hodder 1999, 83), a critical and reflexive process of enquiry which moves between the examination of the evidence and the interpretation of it.

While much of the process of study and interpretation takes place at the building itself, there is also a role for off-site analysis which brings further evidence to bear. Off-site or laboratory analysis, which takes place away from the building, has played a central part in the interpretation of timber structures in particular. Dendrochronology has transformed our understanding by enabling construction to be dated often to within a year. Luminescence dating, while offering less precision, allows the period of manufacture of brick to be identified within broad terms (Bailiff et al. 2010; Blain et al. 2010). The analytical technique which is discussed here, Architectural Paint Research (APR) lies somewhere between the structural analysis of buildings which takes place on site, and the off-site analyses which are 
conducted in the laboratory, providing clarification to the earlier recording work. It is argued below that the interior decorative finishes of a building are an integral part of the structure. We cannot separate the walls, posts and rafters - those structural elements of the building which have been central to the study of its archaeology, from the interior finishes, which have in the past been treated entirely separately. A building is not simply a weather-proof shell in which various unspecified activities of little concern to the recorder take place. The finishes are a fundamental part of the building and by failing to combine their examination into the wider study, we risk an incomplete understanding of the sequence of the structure, as well as its use.

Architectural Paint Research (APR) analyses and interprets the material evidence provided by extant layers of surface decoration applied to a structure throughout its history. The consecutive build-up of these layers demonstrate characteristics that betray the physical and aesthetic changes that have occurred within a structure. In essence, APR is archaeology on a microscopic scale, and its methods of data extraction and interpretation mirror those already familiar to archaeologists. 'Paint samples' excavate the millimetres of decorative deposits in cross-section; 'paint scrapes', or 'uncovering' excavate in plan, and further scientific analysis helps to identify the precise materials present. Knowledge of the history of decorative styles, techniques and technology, and the Law of Superposition (Harris 1989, 3031), locates each decorative layer within a chronological, political, economic, religious, cultural and social framework. Despite the moniker 'paint research', APR refers to all applied surface finishes, including wallpaper, varnish, gilding, stucco and limewash. It is also variously known as 'historic paint analysis', 'architectural finishes research', 'historic decorative finishes research' and other similar phrasings.

APR looks at the appearance, composition and development of decorative finishes, as well as periods of neglect, in order to understand, not only what evidence is (or is not) 
present, but why it is significant. For instance, if a room thought to be a later addition possesses an identical decorative stratigraphy to a room presumed to be part of the original structure, the site's chronology may need to be reconsidered. Alternatively, differing stratigraphy across a single wall may indicate that it had been divided by partitions in the past. If an area thought to be servants' quarters shows evidence of gilded decoration, the historic use of the area, or the living quality of servants, should be reassessed. If a paint layer has a cracked and fissured surface, there is likely to have been a lapse in maintenance of the property at that point. APR thus provides information which can be used to interpret both the use of the site, and its underlying structure.

Beyond the use of APR to understand the sequence of construction and usage, the study also humanizes a building. It allows us access to the personal and public style of the inhabitants, as well as their status, level of comfort, and property maintenance habits. Why did someone choose to paint a room blue? Did they have a choice? Why was wallpaper chosen over paint? Why has one area been painted sixteen times and the adjoining area only five? APR provides evidence of atmosphere; anyone who has walked into a bright red room, or stared at impersonal magnolia walls can attest to the psychological impact that decorative schemes can have (Kopec 2012).

Finally, APR can literally characterize the air that the inhabitants breathed. Significant dirt deposits on a paint surface can indicate a smoggy environment. The atmospheric deposits are trapped between layers of paint, allowing a study of these on a microscopic level.

It is ironic that those layers that are on the peripheries of academic discourse in buildings archaeology, are the ones which would have been most immediate to the occupier. By using Architectural Paint Research as a tool to extract evidence from these finishes, we can glean information that can lead to a more penetrating level of interpretation than currently possible. 


\section{The development of Architectural Paint Research}

APR is not a new technique. The practice of analysing paint finishes in the built environment has its roots in the late 1920s, with the work carried out by Susan Nash during the restoration of (Colonial) Williamsburg, Virginia (Moss 1994). The technique, was more fully developed by Anne F. Clapp and Penelope Hartshorne Batcheler (1968) of the National Park Service, USA, also to inform restoration. Although a rare publication was addressed to an audience of architectural historians (Peterson 1950), by the 1970s dissemination of Architectural Paint Research had decidedly been placed in the category of 'preservation' (Association for Preservation Technology International 1969). Currently, APR in the UK is almost exclusively funded by the commercial heritage sector, on a project-by-project basis. The researcher is therefore pressured to meet the needs of a client - most commonly to record historic decorative schemes, inform conservation and redecoration, or to give an indication of historic significance. Being fostered in a commercial, built heritage environment has also led to reports being written for, presented to, and kept within this audience. When information does filter into academic conversation, it is either wholly restricted to the disciplines of Conservation, and Heritage Science (Moss 1994, Krotzer 2008), or is aimed at an audience that already has an understanding of the technical processes involved (Hughes 2002, Bregnhøi et al. 2006, Jablonski and Matsen 2009). This being said, Bristow's extensive studies of the history of British interiors (1996a) and paint technology (1996b) and Baty's volume, The Anatomy of Colour (2017), which all employ APR to an extent, are aimed at historians rather than conservators. Similarly, Loske's doctoral study (2014), which also attempts to pull APR out of its conservation safety zone, utilizes the pigments identified through commercial APR projects to inform her research into the interior design of Brighton 
Pavilion in the context of contemporary colour theory. Finally, the study of John Fowler: The Invention of the Country-House Style (Hughes 2005) successfully amalgamates APR and research from other historical disciplines to review the work of John Fowler. However, whilst these works introduce APR to a new audience, their cynosure is the history of interior design, and their target audience reflects this. Thus, although Architectural Paint Research is engaging with the conservation, interior design history, and commercial heritage sectors, it is clear that, at present, APR is failing to engage with the wider buildings archaeology community.

\section{The technique of Architectural Paint Research}

Architectural Paint Research takes place both on and off site. It relies on the physical evidence found within a structure, archival research, further material testing, and on-site uncovering providing vital supplementary information. Although all processes are intrinsic to APR, it is the off-site analysis of samples, mounted in resin and viewed in cross-section under a microscope, that is often seen as the defining characteristic of paint research.

Physical investigation begins on site. Samples are removed from areas that will provide the most complete information; nooks and crannies where paint stripping will have failed in its thoroughness. Observations are made that will be valuable in the post-sampling process, for instance the physical characteristics of the paint, or an uneven surface texture under raking light which may indicate a stencilled, or other polychrome design. Off-site, samples are mounted in clear, polyester resin blocks, and polished back so that the paint can be seen in cross-section. These are viewed under a microscope to transform the minute accumulation of paint, varnish, and other decorative applications, into readable deposits (fig. 1). A second site visit, made after samples have been analysed, often involves removing the 
layers of overpaint to excavate in plan a particular decorative scheme/s. This technique is used to create windows through which we can see historic stencilled or trompe l'oeil schemes, (fig. 2) or simply clarify and quantify the colour of the paint (fig. 3) - tasks which cannot be successfully achieved in cross-section under the microscope.

A knowledge of the technological history of paint, pigments, papers and varnishes allows for broad dates to be applied to each layer. Site-specific documentary evidence, such as accounts describing the use of a particular paint mixture, watercolour sketches or photographs, can link layers to even more precise dates. A decorative scheme may be made up of several layers - commonly a primer, undercoat and topcoat. Following the Law of Superposition, the layers closer to the substrate will be older than those closer to the surface. As this process is repeated across all the samples collected from site, certain layers in one sample may be recognized in others, and patterns can begin to emerge. This cross-referencing of samples is crucial to building up a full picture of the history of the area - not only in terms of aesthetics, but also in terms of any physical changes that have taken place.

It is at this point that one of the major drawbacks of APR can become apparent. APR relies on extant evidence. Unfortunately, many redecoration projects involve stripping this evidence, and often one or more historical layers can be missing from a sample. Occasionally, an area may have been fully stripped, and only a couple of layers of modern paint are visible under the microscope. Although the fact that an area was stripped can still impart interesting and useful information, more often than not, lost layers are a frustrating reality of APR research. A second limitation is that paint samples only ever examine a small part of the entire surface area of a space. Each sample may be only a centimetre square. In the context of a ten-metre square room, even taking multiple samples will only reveal a plethora of snapshot histories of the decorative schemes. It takes skill and preparation to identify the most profitable sample locations. The presences of polychrome decorative schemes can 
normally be identified during the initial site survey; the peaks and troughs of the accumulative layers of paint from stencilling or hand-painted designs becoming observable under raking light. However, if these are not identified, then a wall may be misinterpreted as being painted a single flat colour, when in fact, the colour found in the paint sample from this area represents only one of many colours applied across the surface of the wall.

Importantly, not only do the methods of APR give us crucial, material data and historical interpretation, it can also aid in alerting the researcher to hazardous substances. Lead, arsenic, mercury, and asbestos are but a few unpleasant ingredients found within house paints and papers. Knowledge of the presence of these substances can have an impact on research, however it also has practical implications for anyone working within in the property. The method of APR combines on-site survey, scientific investigation, and historical knowledge. It is this multi-faceted viewpoint, and the reciprocal relationship between material and documentary evidence that transforms accumulative layers of paint and other decorative finishes, into meaningful, relevant, and accurate data.

\section{The uses of Architectural Paint Research}

Information is collated from various sources, and analysed to create a viable theory of the different phases of intervention in order to disentangle the construction timeline of a building. These sources can range from documentary evidence, stylistic features, materials used, and evidence from specialist techniques, such as dendrochronology, radiocarbon dating, thermoluminescence and DNA analysis. Architectural paint research provides another source of information, using an archaeological reading of extant decorative schemes to clarify the chronology of a structure.

[subheading] Phase Dating 
A simple example of the use of APR for phase dating structural changes is a door in the 'Cabin Room' of the Nautical Museum, Isle of Man. The Nautical Museum is based in the late eighteenth-century house owned and built by Captain George Quayle - a businessman, banker, sailor, and purported smuggler. Decorated by 1804, the Cabin Room, in the Nautical Museum is an unusual space created by Quayle as an office and apartment (Drury McPherson 2014). Designed to mimic a Captain's cabin room, the small, panelled room exhibits an amalgamation of marine and domestic architectural features. Although Captain's quarters on board ships often contained features borrowed from land-based rooms, examples of the same process being applied in reverse is phenomenally rare. Located directly above a boathouse, which held Quayle's c.1789 schooner-rigged yacht, The Peggy, there are several hidden cupboards and passages by which the cabin room can be entered from the exterior, as well as passages which allow the main space of the cabin room to be completely bypassed. However, there are two unconcealed access points to the Cabin Room in the form of two doors either side of the (fake) fireplace (fig. 4). The door to the right of the fireplace has four glazed panels in the upper half of the door. The door to the left of the fireplace clearly matched this originally, however the upper half of this door is missing a glazing bar, and the glass panels have been replaced with timber panels, suggesting that at some point these had been damaged and blocked-up. It was noticed in raking light that the door once had a decorative border on both the lower, original, and upper, blocked-in, panels (fig. 5). Overlying layers of paint were uncovered on the lower panel, revealing a simple, ochre-colored line on a brown background, likely imitating a veneered inlay (fig. 6). That this appears on the upper and lower panels is, in itself, unremarkable. However, what is of interest is where this decorative scheme lies in the aesthetic chronology of the room. A paint sample removed from the door, showed that this painted line occurred extremely early in the room's history (fig. 7) (McDonnell 2015). The property changed hands in 1835, with alterations 
known to have occurred in 1851 (Drury McPherson 2014). Comparison with other paint samples from the room indicated that the decorative border was applied to the doors before these alterations took place. Furthermore, this was also the only occasion that a decorative line had been painted on the door. This indicates that the glazing in the upper panel of the door was blocked in whilst Quayle was still in residence at the property. Not only does this have an impact on the significance of these seemingly inconsequential rectangles of wood, but it also impacts our interpretation of them. Why did the wealthy Quayle not replace the broken glazing with new? This door leads to a corridor, whereas the right-hand side door leads to an ante-room. Was the glazing blocked in due to privacy, or was it simply difficult to obtain replacements? Was Quayle less attentive to the property if he was planning for it to change hands? Evidence from paint samples cannot answer these questions, yet it can give us the ability to ask them.

The evidence provided by APR gave another insight into the context of the Cabin Room. The earliest decorative scheme found on the doors and panelling of the Cabin Room is a green paint that shows high similarity under visual microscopy to historic paint that composes one of the early, but not earliest, decorative schemes on The Peggy. This creates a physical link between the two structures, and may purport that Quayle intended to create an aesthetic link between the Cabin Room and his beloved boat. However, it also bolsters the documentary evidence used to apply dates to The Peggy and the Cabin Room with material evidence. This demonstrates how Architectural Paint Research can be used to add weight and clarity to existing theories of the order of construction, and provide otherwise unobtainable evidence that can be invaluable to phase-dating structures.

[Subheading] Identifying the Function of a Space 
By delving into the subsurface of walls, APR can extract information that divulges how a space was historically used. A wall on the attic floor of Moat Brae, an early nineteenth-century domestic house and later a nursing home in Dumfries, had clearly been divided at some point in its history (fig. 8). The property was undergoing reconstruction works at the time of sampling, and a large chasm had been made in the wall where presumably a secondary wall would have joined. Furthermore, one half of the wall was painted pink, the other cream. Samples were removed from both halves of the wall to understand better when it had been separated (fig. 9). It was discovered that the wall had always been divided; both halves showed completely divergent decorative stratigraphy (McDonnell 2017). However, although the samples removed from this wall were wildly different from each other, they showed notable similarities to samples taken from elsewhere in the property. The sample from the cream wall showed the same distinctive fingerprint as the paint stratigraphy taken from the corridor areas in the attic. In contrast, the first schemes of paint on the pink wall correlated with those taken from the first-floor rooms. The evidence from the paint elucidated that the wall had been initially divided, confirming what could be seen on site from structural evidence. However, what it further illuminated was that the two distinct areas that each half of the wall was part of, had remarkably disparate functions. Showing the same pattern of paint layers as the attic corridor areas, including two schemes that featured a dark, varnished dado, the cream half of the wall obviously functioned as part of a practical, low-status space, facilitating movement around the property. The pink half of the wall, in contrast, was originally painted in green paints, identically to those of the rooms used as living spaces on the first floor. Arguably, this latter area was one to be lived in, not passed through. Therefore, despite a lack of documentary evidence, it could be reasonably determined which areas of the (semi-dismantled) attic spaces were part of a corridor or landing, and which was part of a living space. Furthermore, it could be determined that a 
room in the attic was afforded the same decorative status as a room on a more principle floors. As the attic floors in Victorian homes were generally the domain of servants and children - both of whom occupied a lower social status than the adults of the house (Mitchell, 1996; Osband, 2002). Thus, not only can paint research can demarcate the original layout of a building, it can also aid in establishing the use of these spaces, and forces us to consider theories that contravene the norm.

[Subheading] Challenging preconceived ideas of high and low status decorative schemes The logic follows that high-status rooms with wealthy patrons will be lavishly decorated in expensive materials, and that low-status buildings with poor inhabitants will be dull and infrequently decorated. However, material evidence challenges these perceived ideas of high and low decoration, and forces us to create new narratives. The tenement houses of New York's Lower East Side were described as 'poor, dirty and wretched' (Elsing 1892). This type of building arose in the 1860s and 1870s to house European immigrants. Reform Acts in the 1900s aimed to improve the overcrowded, windowless apartment, however they also sought to educate their inhabitants in the art of taste (Kittredge 1911; Smith 1905), with the suggestion that 'it is not money that makes comfort or beauty or aesthetic effect in a house. It is thought.' (Smith 1905, 83). Model flats that showed a restrained and simplified design were created, illustrating a sanitary and 'Americanized' style that reformers intended that the tenants would adopt (Hoagland 2018). Apartment 7 of 103 Orchard Street is currently painted 'Navajo White' - the New York landlord's equivalent to magnolia. However, the paint research, undertaken by Jablonski Building Conservation, Inc. in 2012-16 found that, of the thirty-five times it had been redecorated in its history, the current scheme is the only time it has been painted a shade of white (fig. 9) (Hoagland 2018). Previously, the apartment has been painted approximately every three and a half years, in blues, reds, and greens. 
Moreover, schemes that was successfully uncovered (fig. 10), dating from around the 1930s, shows an awareness of fashionable finishes that required a skilled decorator. This finish had a mottled green appearance, and material contrast, that emulated a 'Tiffany Finish'. This was popular in upper class homes in the 1920s, and the style had obviously filtered down through the class system, reaching the tenement occupants by the next decade. Other decorative schemes found within Apartment 7, in public spaces, and other apartments within 103 Orchard Street, mirrored colour schemes that were fashionable in the origin country of the families who had lived there. It seems that the message that 'it is thought, not money', that affects aesthetics, was taken on board by the residents of the Tenement buildings, albeit of a style that was slightly outdated and that reflected the tastes of their native, rather than adopted country. What is clear, through the choice of colour and the frequency of redecoration, is that this does not conform to the narrative that is fed to us through documentary sources (Elsing 1892; Kittredge 1911; Smith 1905) that the living spaces of the poor were depressingly decorated, dirty, or 'wretched', or that spaces were decorated in restrained colours and floral wallpaper as illustrated in photographic evidence of real and 'model' flats. Rather, the evidence suggests that although each room may have been of a similar dimension and social status, the actual appearance may be unique.

York Assembly Rooms is a Grade I listed building, designed by the third Lord Burlington. Completed in 1735, it is one of the earliest examples of a Palladian building in Britain. However, the original decorative scheme of this high-status, public building, was an unpainted, stone-tinted plaster. That was suggested by documentary evidence, and paint research was commissioned to confirm this. APR undertaken by Paul Croft of Lincoln Conservation (Croft 2018), confirmed that the Assembly Rooms were originally a stone colour, which was achieved from a tinted plaster. What was also discovered is that this simple stone scheme was repeated in paint, and remained the accepted colour scheme until 
1860 (fig. 12). At that point, a significant shift occurred in the decorative representation of the building. In contrast to the modest decoration applied over the proceeding centuries, the nineteenth-century scheme devised by Owen Jones was highly decorative, applying variations in colour and tones across different architectural features, and introducing gilding for the first time. The abruptness of this shift is captured in the cross-sections of paint removed from the interior of the building, and gives us evidence not only of what changes occurred by how. In York, this was not a case of a gradual shift from austere neutral colour schemes to high Victoriana, but a sudden demarcation of a new aesthetic. This knowledge of the decorative development of a building, which can have an impact on our interpretation of the history of a building. It also leads us to follow new lines of enquiry; why was a shift in decoration so sudden? How was this received by the public? Although evidence of the contrast between different decorative schemes may be found in documentary sources, APR gives us an instant, compact, and unique insight into the severity of this, based on physical evidence. If no documentary evidence exists, and no structural change has occurred to the building, these microscopic layers of contrasting or complementary colours may be the only evidence that the room has changed at all.

[subheading] Identifying Changes in Environmental Conditions

Deposits of decoration lie on historic surfaces. However, deposited on the decorative surfaces are atmospheric dirt, grime and pollutants. These settle on the surface of a painted structure until the structure is redecorated. At that point, the surface dirt becomes encapsulated between the old and new layers of paint, becoming an intrinsic part of the structure itself. Fluctuations in the build-up of dirt can tell a story greater than that of the decorative history of the object; that of the air around it. This is most evident on exterior structures. A section of railings surrounding Llanelli Town Hall, constructed 1895-96, were 
originally painted in pale grey colours, changing to green, to blue, and finally back to a pale grey (fig. 13). Between these layers of colour however, dirt layers of varying thicknesses are trapped. Paint samples are read like geological deposits. The layers at the top of the image show the most recent decorative schemes. Nineteenth-century Llanelli was an industrial town, made prosperous from the tinplate industry (Morgan 1981). The smog produced from this trade can clearly be seen as thin, dark lines snaking between the layers of grey, leadbased oil paint in the lower half of the sample. Clean Air Acts of 1956, 1968 and 1993 aimed to reduce air pollution in the UK, and the effects of this can be seen through the lessening of dirt build-up. The last significant sediments of dirt occurring around the distinctive, brightyellow zinc chromate primer, and were all but gone by the penultimate three layers of synthetic resin paints, which were not in common use in the UK until around the second half of the twentieth century (Standeven 2007). From an history of decorative finishes point of view, this paint sample demonstrates that there have only been minor fluctuations in colour in these railings over their 120 -year history. However, there is a parallel story is being told that of shifting ideals in society, and the physical effects of legislation in reducing environmental pollution.

Although more noticeable on exterior structures, environmental contaminants can also be seen on interior surfaces; with tarry deposits of cigar smoke, or the charcoalled remnants of tallow candle smoke defining the boundaries between decorative layers. Not only is this a tangible connection to the physical and metaphorical atmosphere of the past, but it can also prove to be a useful tool. Dirt between layers of paint can help to delineate individual schemes. Dirt found on a surface, beneath all overlying paint layers, signifies that it was originally unpainted.

Returning to the paint research undertaken at York Assembly Rooms, analysis of the dirt layers proved essential in identifying the original scheme of the room. Documentary 
evidence suggested that interior stucco on the clerestory walls, completed by John Bagnall, was stone-coloured (Smith 2017). It was expected that, common to numerous other British eighteenth-century interiors, this 'stone colour' would have been achieved through the application of paint. Although tinted plaster was used on the Continent, it has been stated that '[a]uthentic examples of coloured stucco in the British Isles have still, to be satisfactorily proven' (Beard 1986). However, Architectural Paint Research undertaken (Croft, 2018), discovered pigments visible within the plaster of some samples. This evidence suggested that the plaster had been tinted, indicating that the documented stone colour did not come from a decorative paint, as would be commonly expected, but was intrinsic to the plaster finish. The rarity of tinted stucco in the UK could be a cause to doubt the weight of finding a small number of pigment inclusions as proof that the plaster was the final surface of the original decorative scheme. Are the pigments anomalous contaminants? How can it be proven that a paint was not applied and has been subsequently lost? The affirmation lies in the thin, black layer of dirt, can be seen directly between the plaster and the first application of paint in the building (fig. 12). This indicates that the surface of the plaster has been exposed to the atmosphere for a significant period of time - long enough for a layer of smoke-derived grime to build up onto the surface. Furthermore, this layer of dirt can be seen directly on the plaster across multiple samples, both when pigments can and cannot be seen in the plaster. This dissuades the argument that evidence found in a small number of samples is overweighed, and bolsters the case that the stucco plaster was intended as the original decorative finish. Evidence of environmental pollution, therefore, strengthens the argument that York Assembly Rooms is highly significant in being a so-far unique example of the use of unpainted, tinted stucco in an English eighteenth-century interior, and that this technique was used in Britain. Architectural Paint Research, therefore, can be exploited to tell coexisting histories. It is not just the layers of paint, but the microscopic time capsules between them, 
that can inform multi-layered biographies of a structure and its surroundings. They can be used to document environmental change, provide evidence of time passing, as well as aid in the interpretation of the appearance and significance of a building.

\section{[Subheading] Understanding Aesthetics}

Fisher and Maffei argue 'It is perhaps the quality of objects' surfaces that most clearly establish their presence and our relationship to them' (Fisher and Maffei, 2013, 231). Paint is made of four components; pigments (to give colour), a binder (to hold everything together), an extender or bulking agent (to give the paint body), a solvent (to allow the paint to be applied as a liquid), and occasionally a drier (to help the paint become a solid). Each one of these components changes the final appearance of the paint. For instance, soft distemper paints are water-based with a glue binder, and are soft and powdery in texture. Oil-bound paints can be satin or highly glossy depending on how much turpentine was added. The distinct surface texture of the most common historic decorative finish; lead white paint, still cannot be accurately reproduced by modern (non-toxic) alternatives (Mitchell Rose 2002). Further to this, paints were historically mixed by the decorator by hand, creating paint with unique and oscillating hues, opacity, and gloss when applied to a surface (Bristow 1996). As such, documentary evidence of a room being painted a 'green colour' can only give partial explanation into the materiality of the room.

The Marble Closet at Little Castle Bolsover is a small space on the first floor, intended as an intimate withdrawing room. Constructed in 1616, it gets its name from the black-and-white marble floors, fireplace and vaulted ceiling. However, documentary evidence describes its refitting $c .1676$, with crimson taffeta hangings set over softwood panelling; this decorative scheme was also illustrated by John Smythson. Three hundred years, and several decorative schemes later, the panelling was overpainted a modern blue 
paint, and the hangings had been long since abandoned (fig. 14). In its modern iteration, the idea that this space offered an inviting space to withdraw required some imagination, and the space had a 'uniform and sanitised appearance' (Hughes 2010, 3). It was presented as a historic relic; an aloof room in a house built by long-dead inhabitants. Architectural Paint Research by Helen Hughes (2010) led to the full restoration of the 1676 scheme. Hughes found that the panelling that covers the walls of the room was originally painted in a green, copper resinate glaze, over a green-tinted lead based oil paint (fig.15). A glaze is not a flat colour, but a translucent finish that gives dimension, an almost intangible depth, to the wall particularly when viewed under vacillating firelight. This is also an extremely costly decorative finish, and would have proliferated that specific ambiance of comfort only achievable by being a wealthy individual in the eighteenth century. In actual fact, copper resinate glaze had not been formulated since the eighteenth century. Analysis of this glaze revealed the ingredients within it, and experimentation by modern decorators established the correct ratios of these components to make it possible to recreate an applicable formula (fig. 16). Therefore, the reformulating of this paint for redecoration allowed this aesthetic to be understood first hand for the first item in several centuries. The research also revealed that this glaze had only been applied to the outer edges of the panelling, and the only fully painted panels were those flanking the French window on the west wall, and the over-door panel on the north wall. This demonstrated that the hangings were absolutely intrinsic to the design of the room. The crimson drapery had appeared in primary designs of the Marble Closet, yet it was not until the realization that the copper-resinate glaze had been applied around where they hung, that their importance was recognized. Knowledge of the appearance of the room based on material analysis is interesting. However, the real value of results of APR on this project is that they highlighted just how far we fail to acknowledge the importance of interior design as an integral component in the representation and understanding of a room. 
Furthermore, the reinstatement of these schemes, facilitated by APR, provided the opportunity for the impact of this change in decoration to be experienced. This underlines the fact that a complete interpretation of a room requires more than archival research, and an understanding of structural change. Changing the decorative finish of the Marble Closet, both in terms of the texture and colour of the paint, and the introduction of soft furnishings, means that the room can be perceived in the comfortable, welcoming aesthetic expected from a withdrawing room. The evidence provided by Hughes' paint research not only enforced the importance of the hangings within the room, and gives unprecedented insight into the surface quality of the walls, but is also forces us to readdress the significance of historic decorative surfaces.

[Subheading] Ideology versus Practicality in Building Construction Finally, Architectural Paint Research can shift our perspective on accepted theories of the ideologies that a building represents. It provides material truths which can undermine documented statements, sometimes by the architect themselves, and pull into harsh, but fascinating daylight, the reality that buildings are always a practical achievement, regardless of cognitive tenets. The geometric, cast concrete shapes that made up the K. B. Hallen building, Denmark, define it as an outstanding example of modernist architecture. Designed by Hans Hansen, and constructed in 1938, the building made use of modern materials, including the well-publicized use of Creconto - a paint specifically designed to be applied to fresh concrete (fig. 17) (Bornemann Mogensen et al. 2018). The alkaline nature of newly cast concrete meant that traditional oil paint, based predominantly on linseed oil, would fail. As concrete could take up to several years to cure fully, Creconto was a welcome solution to a significant problem (Paulsson and Wanscher, 1938). Paint research and analysis undertaken by the National Museum of Denmark, found evidence that corresponded with the architect's 
original specifications for the exterior of the building to be painted in red, white and blue using Creconto paint (Bornemann Mogensen et al. 2018). An ultramodern coating for a new material to create a modernist building; the use of Concreto on the exterior of K. B. Hallen seemed to fulfil both practical and ideological demands. Conversely, analysis of the paint found that the interior of the building had been painted in traditional limewash and distemper, or distemper-emulsions (fig. 18), the latter of which had been in practical use since at least 1908 (Hasluck, 1908). This juxtaposition between the new and the traditional may have been due to practical reasons; unlike oil paints, lime wash and distempers do not react with uncured concrete. However, distempers also have poor durability, and are not an obvious choice for rooms that experience high traffic. K. B Hallen was originally designed to be a public sports arena, and therefore expected to handle large quantities of people moving around the space. Furthermore, the same paint company that produced Creconto, also produced an interior paint for use on uncured concrete, Saniton. Why, then, was the decision made to apply traditional finishes to the interior of the building? Bornemann Mogensen et al. (2018) speculated that cost, known compatibility with concrete interiors, ease of repainting, and a familiarity of painters with these more traditional paints may all have been factors in the decision to use limewash and distempers or emulsion paints over a more modern paint type. Regardless as to why, simply knowing that the K. B. Hallen incorporates traditional materials and techniques is important in informing our understanding of it. The results of the Architectural Paint Research conducted by the National Museum of Denmark transforms the K. B. Hallen from a modernist building on the precipice of technological advancement, to a structure that epitomized the transition between traditional and advanced techniques; a balance between progress and pragmatism. APR gave the opportunity to ask the questions needed to arrive at this conclusion, and, in doing so, to re-evaluate how we perceive a building. Furthermore, APR provided a method of identifying the extent to which written 
specifications correspond to the decorative finishes actually applied. In the case of K. B. Hallen, paint research proved that the specification of using red, white, and blue Conreto point was carried out on the exterior. This ability to compare documentary findings with material evidence, noting and evaluating consistencies and discrepancies, further aligns APR with buildings archaeology.

\section{Conclusion}

Buildings archaeology seeks to understand the development of historical structures. It traces the history of alterations to the interior and exterior of a building based on evidence given by the standing structure; its stylistic features, materials, and contextual relationships of extant elements, as well as the scars left by modifications. Growing out of the examination of, often Reformation-ravaged, churches, at its inception, this field of study did not have a pressing need nor ample opportunity to study applied decoration, although innate decoration such as carved foliage was examined. Whilst other forms of focused analysis, such as dendrochronology and luminescence dating, have become an expected aid to building archaeologists, it is perhaps due to this early historiography that the discipline neglects to incorporate the analysis of surface finishes into the interpretation of the structural development of a building. In conjunction with this, Architectural Paint Research has marginalized itself into the worlds of conservation and commercial heritage, and thus failed to publicize itself to a broader historical and archaeological audience. 
That APR is not made available to, or made use of by, buildings archaeologists is ironic seeing that APR is, fundamentally, a form of archaeology. Within each paint sample, changes that may have occurred over centuries are compacted into stratigraphy millimetres thick, and, when multiple cross-sections are analysed, a picture of the chronology of the structure can be built up. This is achieved using the same principles and thought processes in other fields of archaeology; a combination of visual analysis of material evidence, archival sources, and contextual knowledge. Supplementary evidence is extracted through focused analysis of individual finds; identification of a specific pigment within a paint layer informs APR in the same way that a sherd of pottery, or a beam dated using dendrochronology informs dirt and buildings archaeology respectively.

Furthermore, amalgamating findings from APR and buildings archaeology is mutually beneficial. There is strength in the combined knowledge of different disciplines. APR is based on material evidence, but it must be combined with a broad knowledge base to become meaningful. An understanding of the structural development of a building, and the use of a space, aids APR practitioners in creating a sampling plan which can select historically relevant or dateable locations, giving greater probability of discovering an original or significant decorative scheme, or of dating individual paint layers. On the other hand, the ability of APR to not only reveal an original aesthetic and environment, but also to look at how these have has evolved over time can facilitate building archaeologists in crafting new interpretations of a space, and to deconstruct the aesthetic stage-sets we give to different historical time periods, societies, and building types.

Rooms cannot be dissociated from how the way they were decorated. The decorative finish is the final face of the room; an ephemeral but intrinsic part and, as such, a space cannot be fully interpreted without knowledge of its applied aesthetics. The surface texture, gloss, and colour, on the walls, floor and ceiling can transform how a space is perceived. A room 
covered in soft, floral wallpaper will produce a completely different experience from the same space painted in a crisp, white emulsion paint, and different again if left in bare brick even the lack of decoration perpetuates some sense of atmosphere.

Beyond this, however, the investigation of decorative schemes can disclose the chronology of a building's structure, aiding in phase dating. It can disclose the function that spaces performed, giving physical evidence of this when no other evidence exists. It challenges assumptions about historic decoration, built on bias or incomplete archival evidence. It can measure the extent to which a building abetted ideological principles in favour of necessary practicalities. Finally, the detritus encapsulated between decorative schemes can divulge information about environmental conditions. It is this scope, this breadth of data, that can provide immeasurable value. It is hoped that, in the future, APR will be used by building archaeologists as an intrinsic tool to study these transient but essential layers of a building, and give greater meaning to the structure as a whole, and the society and individuals who created, manipulated, and populated it.

\section{References}

Association for Preservation Technology International. 1969. Paint Color Research and House Painting Practices, Newsletter of the Association for Preservation Technology 1 (2): $5-20$ 
Bailiff, I. K., Blain, S, Graves, C. P., Gurling, T. and Semple, S. 2010. "Uses and recycling of brick in medieval and Tudor English buildings: insights from the application of luminescence dating and new avenues for further research.” Archaeological Journal 167: 165-96

Batcheler, P. 1968. "Paint Color Research and Restoration.” History News 23 (10): 183-86

Baty, P. 2017. The Anatomy of Colour. London: Themes and Hudson

Beard, G. 1986. Craftsmen and Interior Decoration in England 1660 - 1820. London:

Bloomsbury Books

Blain, S., Bailiff, I. K., Guibert, P., Bouvier, A. and Baylé, M. 2010. “An intercomparison study of luminescence dating protocols and techniques applied to medieval brick samples from Normandy (France)." Quaternary Geochronology 5: 311-16

Bold, J. 1900. "The recording of standing buildings." Vernacular Architecture 21: 16-17.

Bornemann Mogensen, J., Christian Christensen, M., Mortensen, M. N. \& Taube, M. 2018. K.b. Hallen: a modernist building in transition between tradition and industrial evolution. In Macro to Micro: Examining Architectural Finishes. Edited by M. Jablonski and K. Travers Moffitt. London: Archetype.

Bregnhøi, L., Hughes, H., Lindbom, J., Olstad, T., and Verweij, E. eds.. 2006. Paint Research in Building Conservation. London: Archetype 
Bristow, I. C. 1996a. Architectural Colour in British Interiors, 1615-1840. London: Yale University Press

Bristow, I. C. 1996b. Interior House-painting Colours and Technology, 1615-1840. London: Yale University Press

Croft, P. 2018. “Architectural Paint Research: York Assembly Rooms.” Unpublished commercial report. University of Lincoln.

Cushman, A.S. 1908. “The Corrosion of Iron.” Science. 27(695): 666

Degerblad, K. H., and Nilsen, L. eds. 2014. Standards in Architectural Paint Research. London: Archetype

Drury McPherson Partnership. 2014. The Nautical Museum and The Peggy, Castletown, Isle of Man: Conservation Management Plan. Drury McPherson Partnership [unpublished].

Elsing, W. T. 1892. "Life in New York Tenement-Houses as seen by a City Missionary”. Scribner's. 11.

Faulding, R. and Thomas, S. eds. 2014. Architectural Paint Research: Sharing Information, Sharing Decisions. London: Archetype

Ferris, I. M. 1989. “The archaeological investigation of standing buildings.” Vernacular Architecture 20, 12-17 
Ferris, I. M. 1991. “I am not a camera.” Vernacular Architecture 22: 1

Fisher, T., and Maffei, N. P. 2013. "Historicizing shininess in design: finding meaning in an unstable phenomenon.” Journal of Design History 26(3): 231-40

Harris, E. C. 1989. Principles of Archaeological Stratigraphy (second edn). London: Academic Press

Hasluck, P.N..1908. Cassell's House Decoration: a practical guide to painters' and decorators' work. London : Cassell \& Co. p.125

Historic England. 2016. Understanding Historic Buildings: A Guide to Good Recording Practice. Historic England

Hoagland, S. M. 2014. “From pauper to prince: reinterpreting St. John’s Colonial Building through decorative finishes." In Standards in Architectural Paint Research. Edited by L. Nilsen and K. Hinrichs Dergerblad. London: Archetype Publications Ltd. 145-152

Hoagland, S. M. 2018. “The tasteful tenement: forgotten finishes at the Lower East Side Tenement Museum, New York." in Macro to Micro: Examining Architectural Finishes. Edited by M. Jablonski and K. Travers Moffitt, London: Archetype Hodder, I 1999. The Archaeological Process. An Introduction. Oxford: Blackwell Hughes, H. 2010. "Interdisciplinary collaboration to understand and recreate the splendour of the Marble Closet at the Little Castle Bolsover". In Proceedings of the Joint Interim Meeting. Multidisciplinary Conservation: A Holistic View For Historic Interiors. Rome 23-26 March 2010 ICOM-CC. Edited by E. Janssen, M. Paris, M. Sawicki, K. Seymour, and A. Thorn, A. 
http://www.icom-

cc.org/142/Multidisciplinary\%20Conservation:\%20A\%20Holistic\%20View\%20For\%20Hist oric\%20Interiors\%20Rome\%2023-26\%20March\%202010/\#.W9htlBP7TBI

Hughes, H. ed. 2002. Layers of Understanding: Setting Standards for Architectural Paint Research. Shaftesbury: Donhead Publishing

Jablonski, M. A. and Matsen, C. R. eds. 2009. Architectural Finishes in the Built Environment. London: Archetype

Johnson, M. 2010. English Houses, 1300-1800: Vernacular Architecture, Social Life. Harlow: Pearson Longman.

Kittredge, M. ed. 1911. Housekeeping Notes: How to furnish and keep house in a tenement flat. Boston: Whitcomb and Barrows.

Klein, Jr., F.D. 1942. Process Practices in the Aircraft Industry. New York: McGraw-Hill Book Company

Kopec, D. 2012. Environmental Psychology for Design. New York: Fairchild Books

Krotzer, D. S. 2008. “Architectural finishes: research and analysis.” APT Bulletin: The Journal of Preservation Technology 39(2/3): 1-6

Leach, N. 1997. Rethinking Architecture. London: Routledge 
Locock, M. 1994. Meaningful Architecture: social interpretations of buildings. Aldershot: Avebury Press

Loske, A. 2014. “The Decorative Scheme of the Royal Pavilion, Brighton: George IV's Design Ideas in the Context of European Colour Theory, 1765 - 1845" PhD diss. University of Sussex

McDonnell, P. 2015. "Research and analysis of Historic Decorative Schemes: Cabin Room, Nautical Museum, Isle of Man.” Unpublished commercial report. University of Lincoln McDonnell, P. 2017. “Moat Brea, Dumphres, Scotland.” Unpublished commercial report. University of Lincoln.

Meeson, B. 1989. “In defence of selective recording.” Vernacular Architecture 20: 18-19.

Mitchell Rose, C. 2002. “Traditional Paints.” The Building Conservation Directory. Accessed 30th October 2018. http://www.buildingconservation.com/articles/paint/paint.htm

Mitchell, S. 1996. Daily Life in Victorian England. Westport, CT: Greenwood Press.

Morgan, K. O. 1981. Rebirth of a Nation: Wales 1880 - 1980. New York: Oxford University Press; University of Wales press.

Morris, R. 2000. The Archaeology of Buildings. Stroud: Tempus 
Moss, R. W. 1994. Paint in America: The Colors of Historic Buildings. Washington D.C.: Architype Press

Osband, L. 2002. Victorian House Style. Newton Abbot: David and Charles.

Paulsson and Wanscher, O. 1938. Muroerk og jernbeton. Copenhagen: Egmont H. Pertens Kgl. Hof-Bogtrykkeri.

Peterson, C. E. 1950. "Early sanded paint finish, American Notes section." Journal of the Society of Architectural Historians 9(3): 23-24

Revision A, 18th May 2017.” Unpublished commercial report. Prepared for York Conservation Trust

Samson, R. Ed. 1990. The Social Archaeology of Houses. Edinburgh, Edinburgh University Press.

Sanchez Goodwillie, E. and Mills, C. 2018. "From Pigment particles to Parlour walls: contemporary practice in the reproduction of historic paints." In Macro to Micro: Examining Architectural Finishes. Edited by M. Jablonski and K. Travers Moffitt. London: Archetype.

Smith, B. 1905. "The gospel of simplicity as applied to tenement houses." The Craftsman 9: $81-91$

Smith, Dr., D. 2017. “The Assembly Rooms, Blake Street, York. Statement of Significance, 
Smith, J. T. 1989. "The archaeological investigation of standing buildings: a comment." Vernacular Architecture 20: 20

Standeven, H. 2007. "Cover the earth: a history of the manufacture of household gloss paints in Britain and the United states from the 1920's to the 1950's.”. In Modern Paints Uncovered: Proceedings from the Modern Paints Uncovered Symposium. Edited by T. Learner. Los Angeles: Getty Publications.

Van Eikema Hommes, M. 2012. Art and Allegence in the Dutch Golden Age: The Ambitions of a Wealthy Widow in a Painted Chamber by Ferdinand Bol. Amsterdamn: Amsterdamn University Press.

Verslype, I., Sigmond, H., Harmanni, R., Keune, K., and van Eikema Hommes, M. 2018. “The original appearance of the 'painted chamber' in Huis de Dieu, Alkmaar (1742-1744): the discovery of a remarkable finish." In Macro to Micro: Examining Architectural Finishes. Edited by M. Jablonski and K. Travers Moffitt. London: Archetype.

Verslype, I., Sigmond, H., Harmanni, R., Keune, K., and van Eikema Hommes, M. 2018. “The original appearance of the 'painted chamber' in Huis de Dieu, Alkmaar (1742-1744): the discovery of a remarkable finish." In Macro to Micro: Examining Architectural Finishes. Edited by M. Jablonski and K. Travers Moffitt. London: Archetype.

Welsh, F. W. 1986. "Who is an historic paint analyst? A call for standards'." APT Bulletin: The Journal of Preservation Technology 18(4): 4-5 
Welsh. F. W. 1982. "Paint analysis." Bulletin of the Association for Preservation Technology 14(4): 29-

Wood, J. ed. 1994. Buildings Archaeology: applications in practice. Oxford: Oxbow 


\section{Figures}

Figure 1 - Paint sample from a column capital at Wakefield Town Hall, mounted and viewed in cross-section under visible light at x100 magnification. The red paint at the top is the most recent layer. The sample contains layers of modern and historic paint, gildings, marbling, and textured (sanded) paint. (Image: Lincoln Conservation, 2019)

Figure 2 - Example of paint uncovering. The brown overpaint was removed using scalpels to reveal a trompe l'oeil marbling scheme on a fluted column in St George's Chapel, Great Yarmouth. (Image: Paul Croft, University of Lincoln, 2012)

Figure 3 - Stratigraphic uncovering on an interior wall at K. B. Hallen. This 'matrix' uncovering allows for each paint scheme to be seen in plan. (Image: Johanne Bornemann Mogensen, The National Museum of Denmark 2015)

Figure 4 - Unconcealed doors to Cabin Room (Image: Phillipa McDonnell, University of Lincoln, 2015)

Figure 5 - Door panel in raking light, showing decorative boarder (Image: Phillipa McDonnell, University of Lincoln, 2015)

Figure 6 - Uncovering of decorative boarder (Image: Phillipa McDonnell, University of Lincoln, 2015) 
Figure 7 - Paint samples from decorative boarder on doors, and from paint sample from the wooden panelling in the room. The green layer directly beneath the painted boarder layer is coeval with the first scheme on the wooden panelling in the room. This indicate that the subsequent boarder was an early decorative scheme (scheme 1a). (Image: Phillipa McDonnell, University of Lincoln, 2015)

Figure 8 - Attic landing wall, Moat Brae (Phillipa McDonnell, Lincoln Conservation, 2017)

Figure 9 - Comparison of samples from Moat Brae. Note how samples from the first-floor room and pink half of the attic landing wall show the same early paint layers, whereas the cream half of the attic landing wall shows the same early layers as an attic corridor. (Phillipa McDonnell, Lincoln Conservation, 2017)

Figure 10 - Wall Glazes from the living room (top) and dining room (below) of Apartment 7, Lower East Side Tenement Museum. (Image: Stephanie M. Hoagland, Jablonski Building Conservation, Inc.)

Figure 11 - Photomicrographs of paint samples from walls of Apartment 7, Lower East Side Tenement Museum. From left: living room, entrance hall, and bedroom. (Image: Stephanie M. Hoagland, Jablonski Building Conservation, Inc.)

Figure 12 - Paint sample from cornice modillions at York Assembly Rooms (Image: Paul Croft, Lincoln Conservation, 2017)

Figure 13 - Paint sample from Llanelli Town Hall railings. No dirt can be seen between the later layers of paint at the top of the image, whereas lines of black dirt deposits can be seen between 
layers of older paint at the bottom of the image. (Phillipa McDonnell, University of Lincoln, 2015)

Figure 14 - Marble Closet window wall with blue paint applied in 1976 (Image: Helen Hughes, 2010)

Figure 15 - Marble closet, photomicrograph of cross-section of copper resinate glaze applied to softwood (Image: Helen Hughes, 2010)

Figure 16 - Marble Closet, Tom Greening applying new copper resinate glaze (image: Helen Hughes, 2010)

Figure 17 - Advertisement for Creconto paint. (Image: Arkiekten, 1938. Reproduced by Johanne Bornemann Mogensen, The National Museum of Denmark, 2018)

Figure 18 - Chromatogram from the GC-MS analysis of paint sample number 2 from K.B. Hallen. The listed compounds are the carboxylic acids that correspond to the methyl ester derivatives actually recorded in the GC-MS. This helps to determine the type of paint used. (Image: Martin N. Mortensen, The National Museum of Denmark, 2016) 


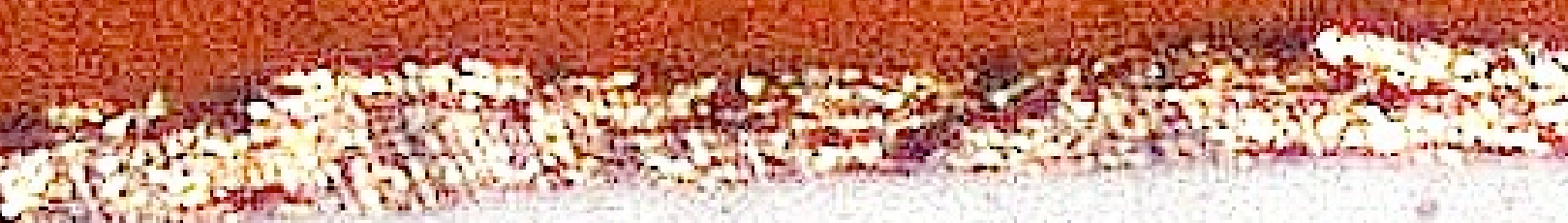

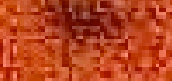

(2.

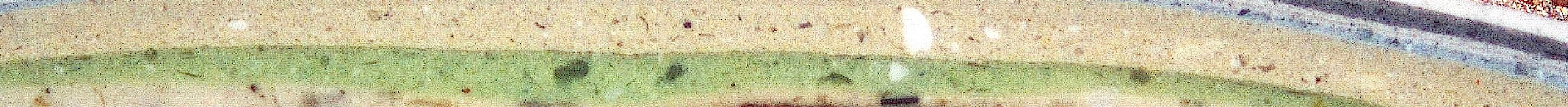

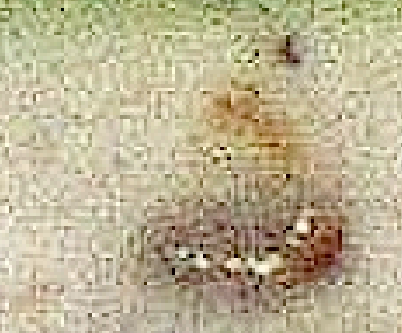

28

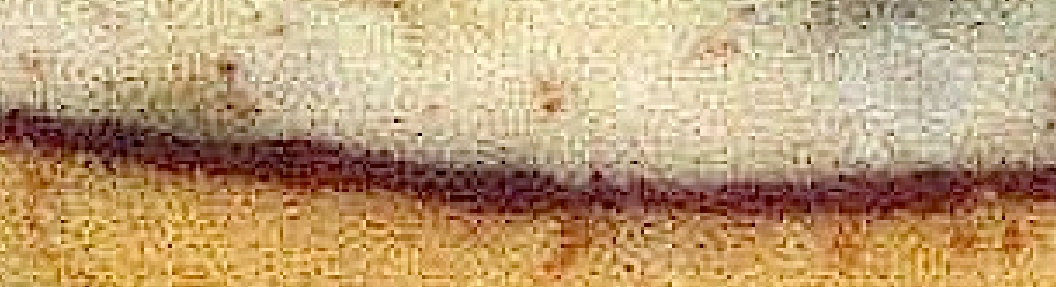

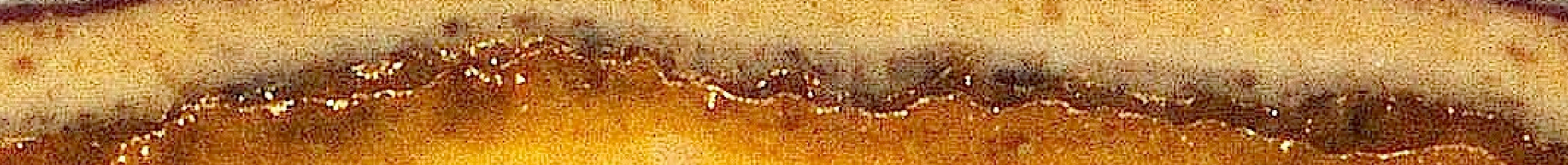

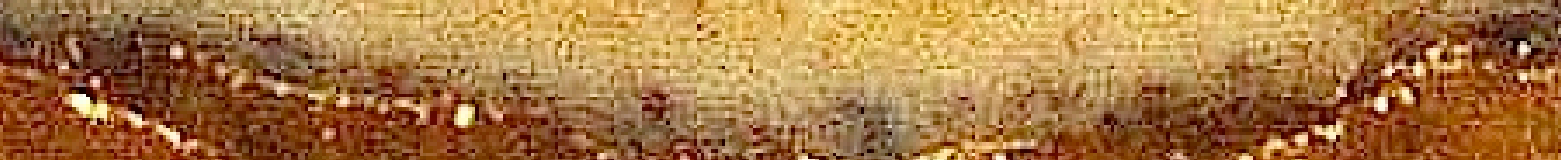






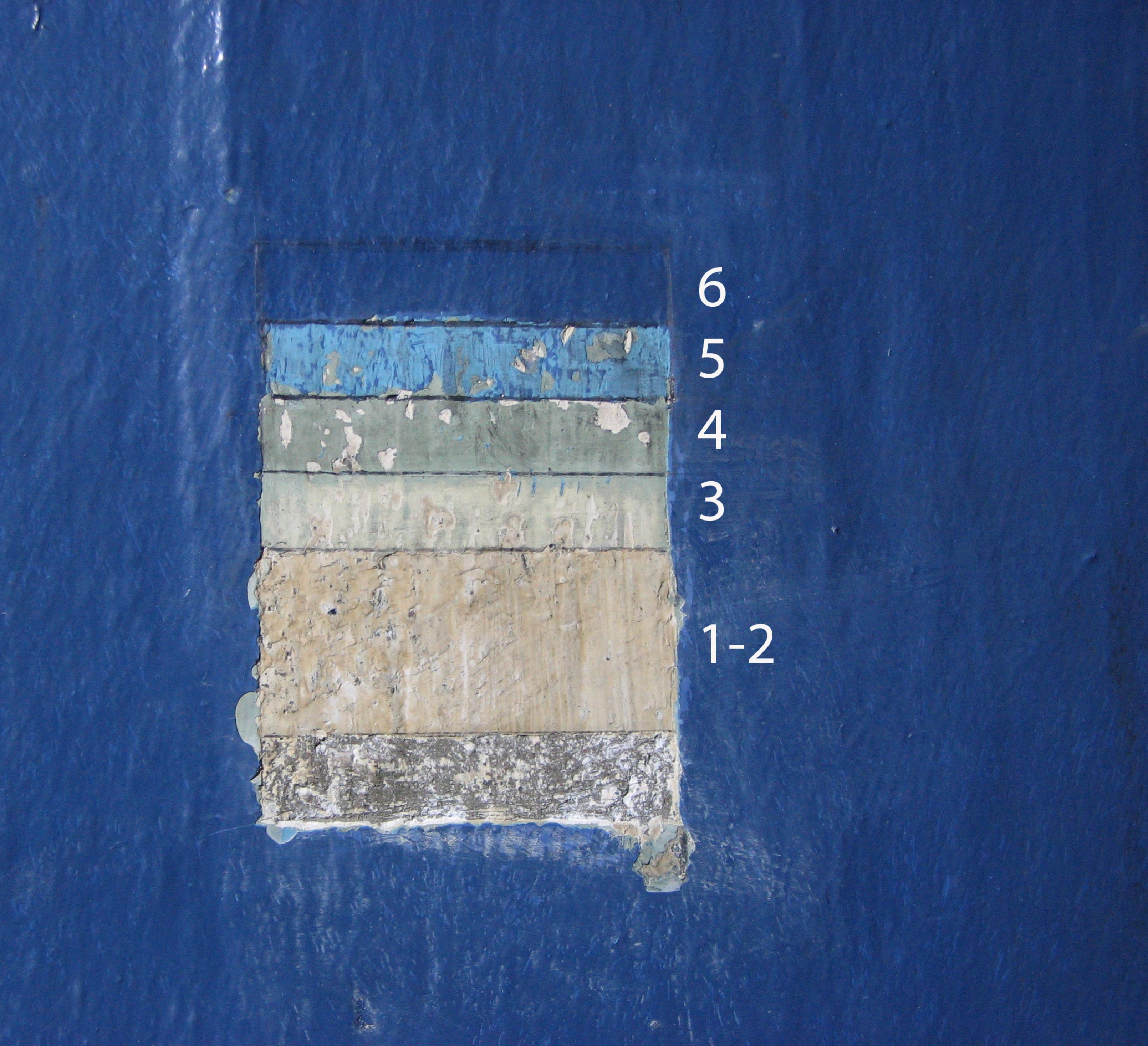



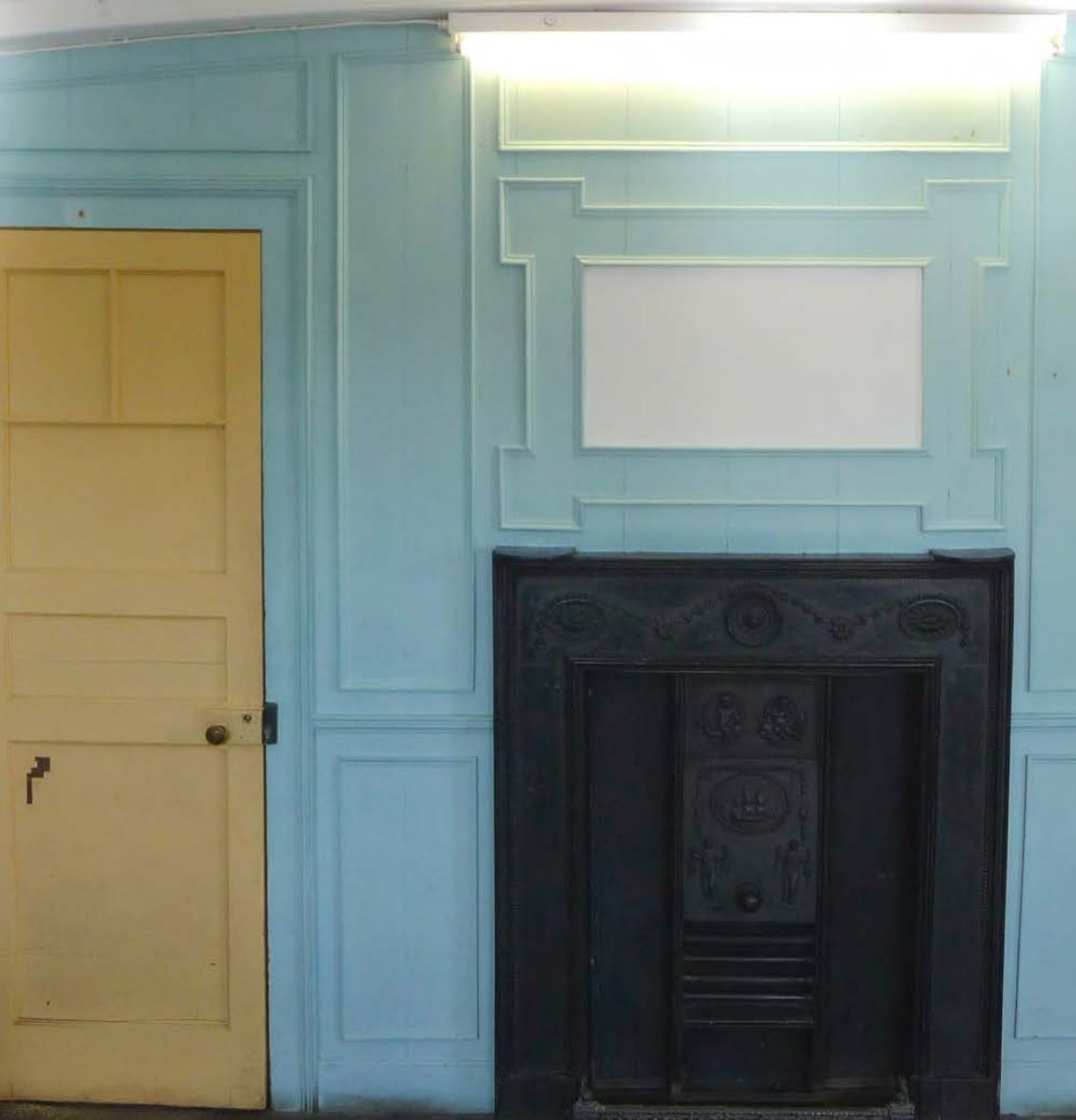

(5)

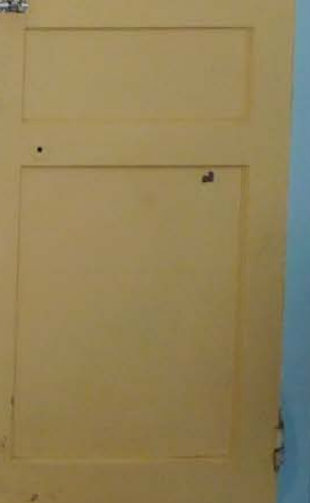





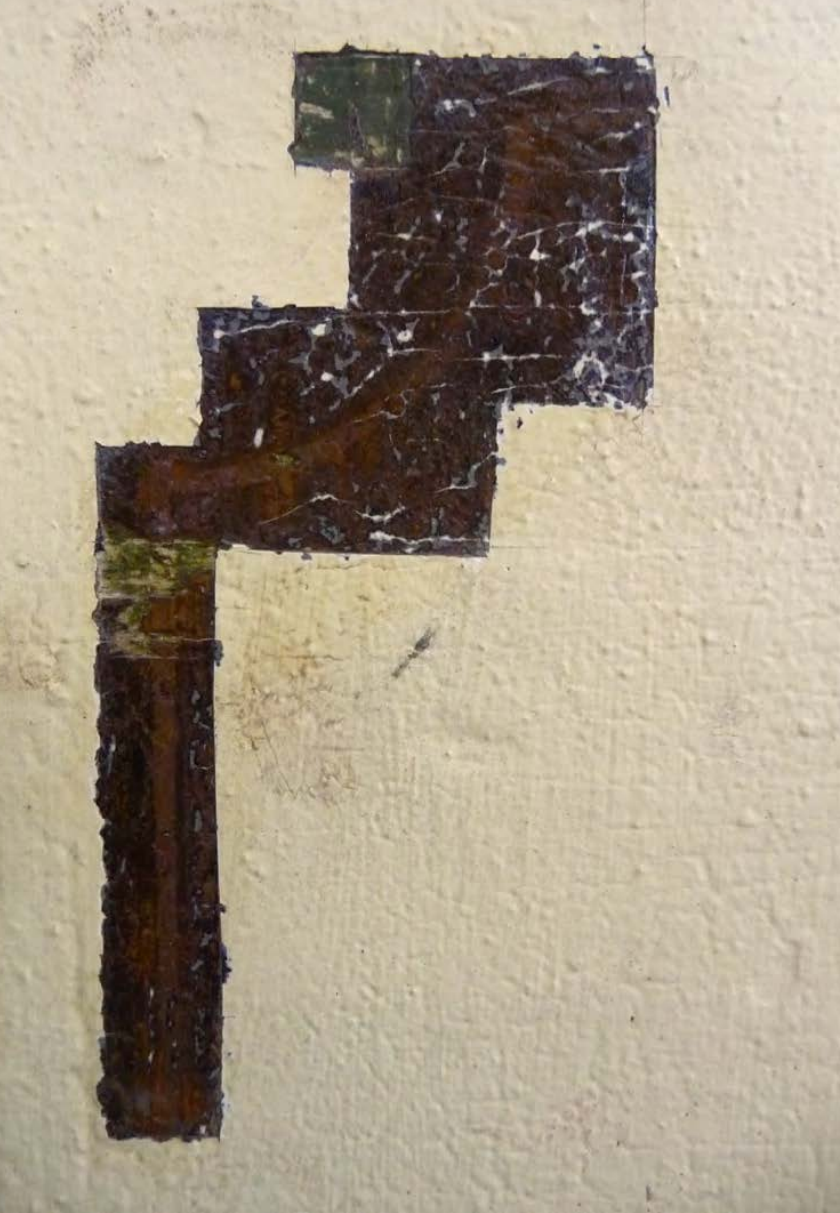




$$
\times 200 \text { magnification }
$$

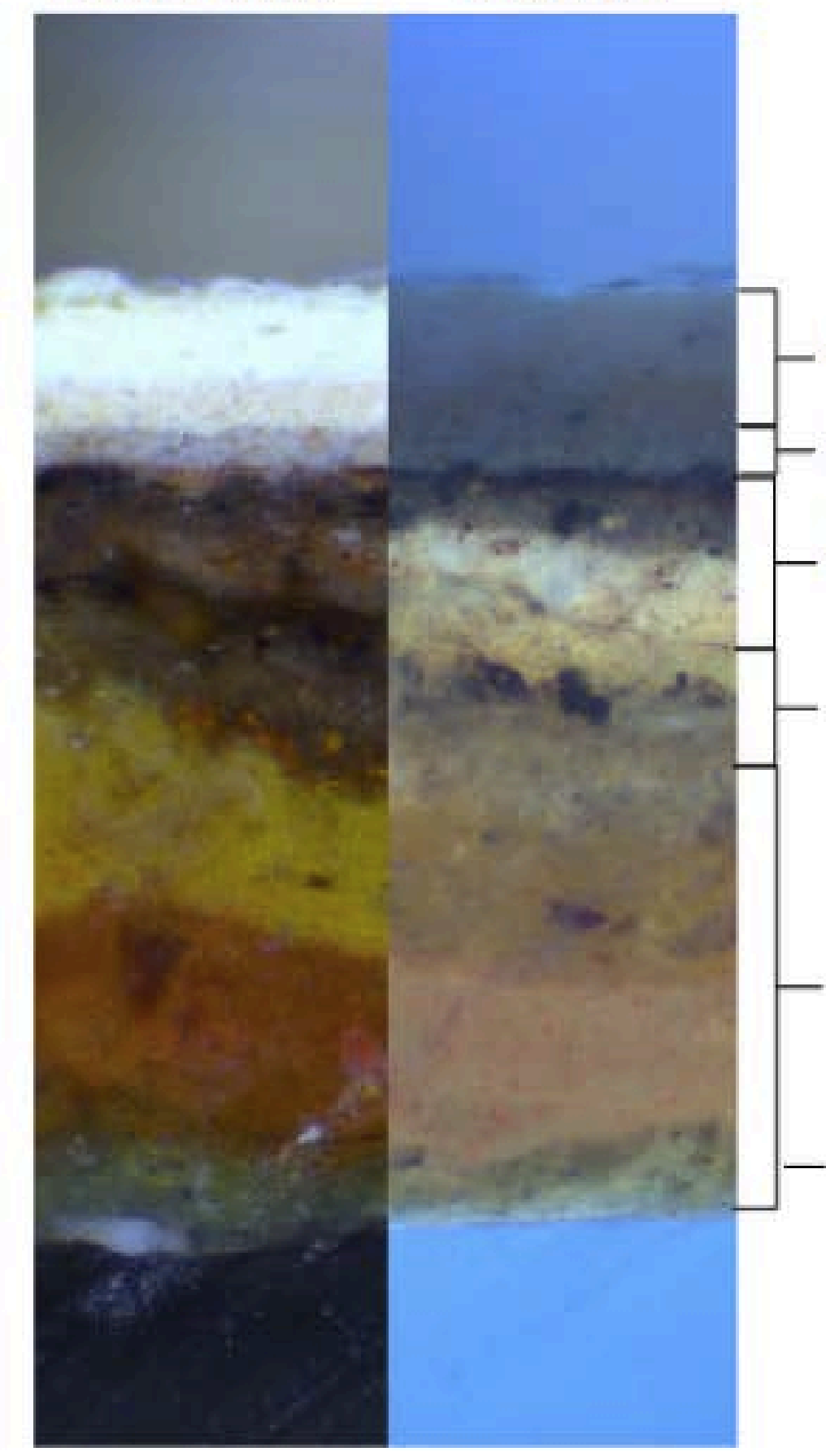

5CHEME 4 - Grey lead oilpaint

SCHEME 3 - Brown lead

oilpaint with basecoat

SCHEME 2 - Brown lead

oilpaint with basecoat

SCHEME la- Varnished

decorative ochre border over brown lead oil paint.

SCHEME 1 - Green lead oilpaint with basecoat

Red lead primer and wood substrate lost.

\section{Sample 6.27 - lower wallface panel moulding $\times 200$ magnification
Simulated daylight
ultraviolet light

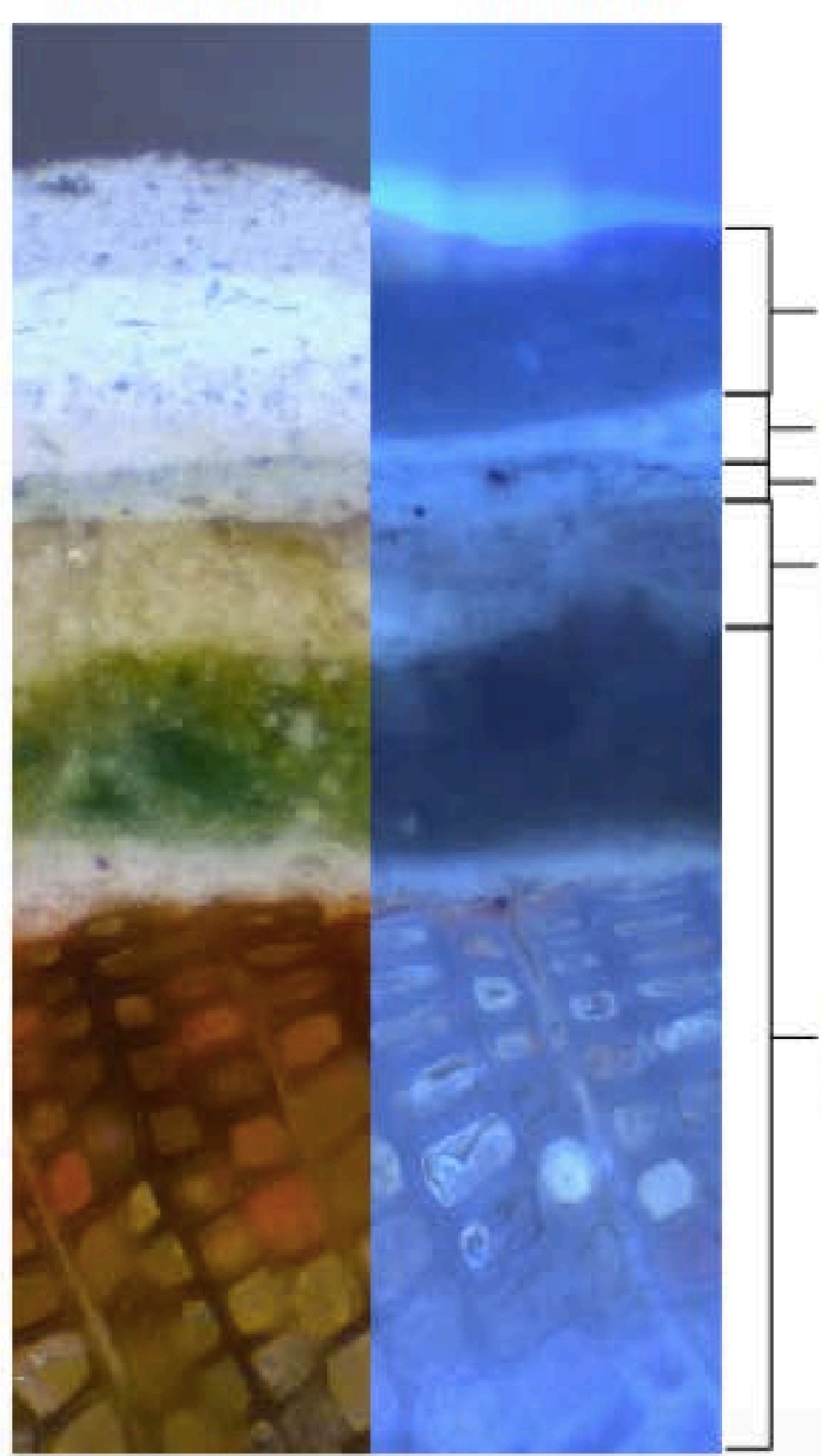

SCHEME 5 - glue alkyd paint

SCHEME 4 - Grey lead oilpaint SCHEME 3 - Grey-cream lead oilpaint

SCHEME 2 - Grey-cream

lead oilpaint with basecoat

SCHEME 1 - Green lead oilpaint with basecoat and red lead primer and wood substrate 


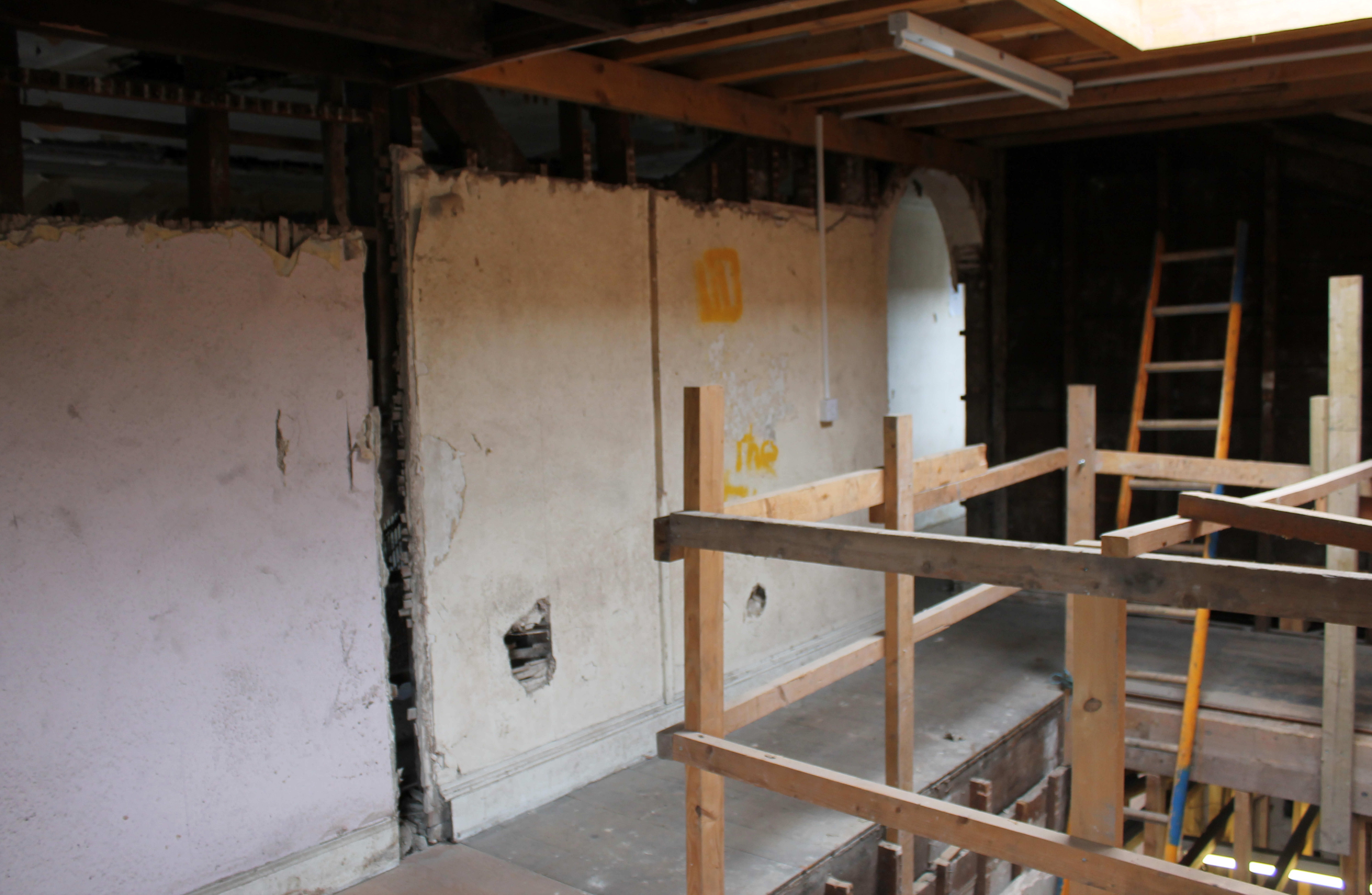




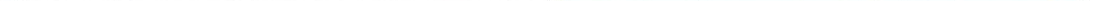




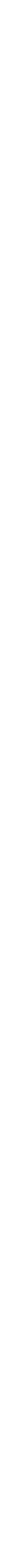



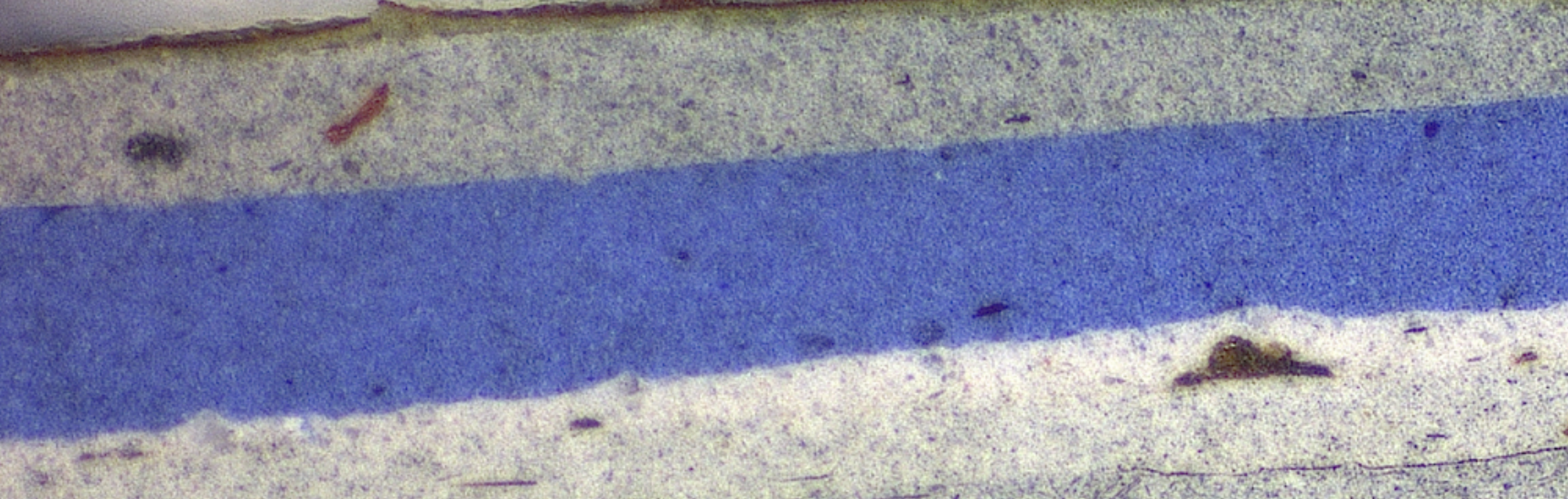

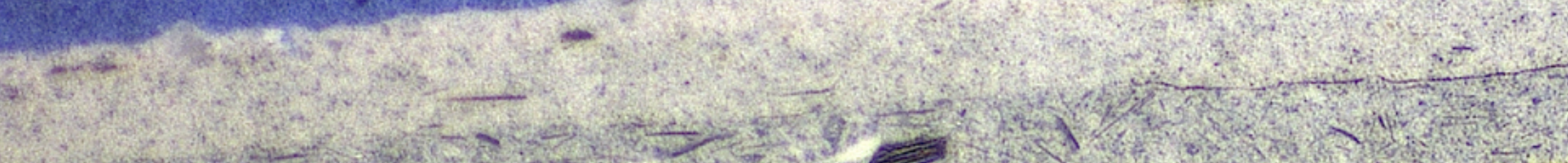

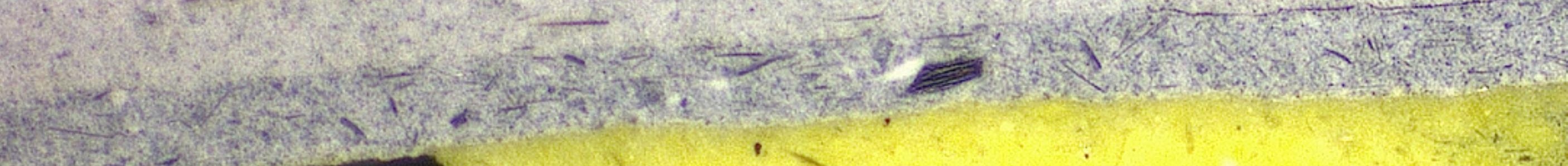
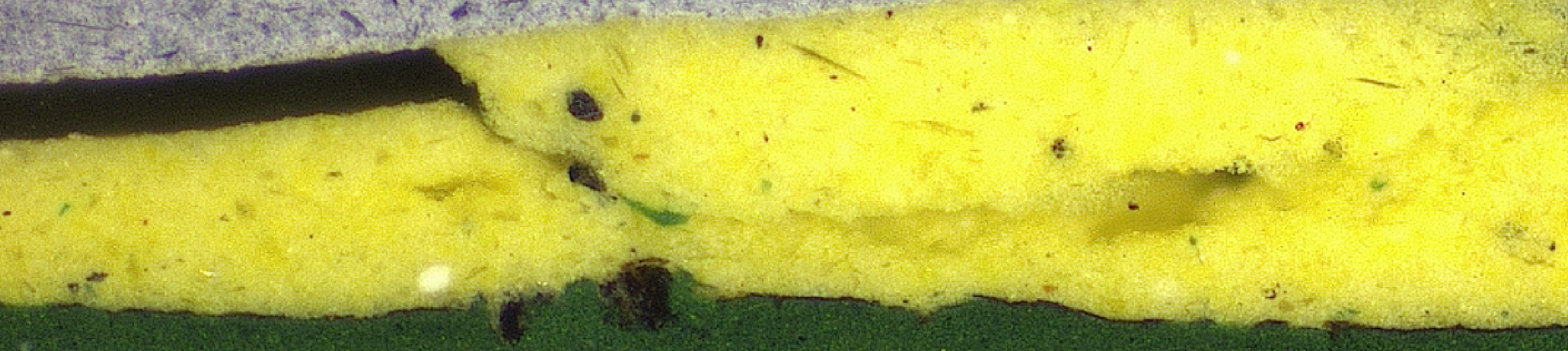

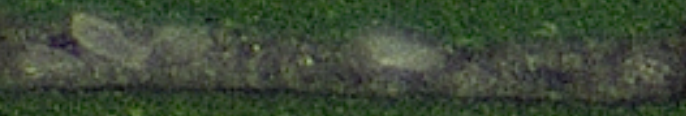

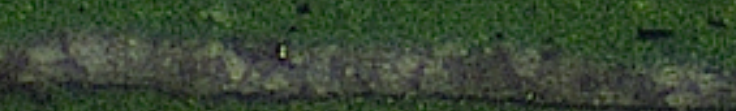

5

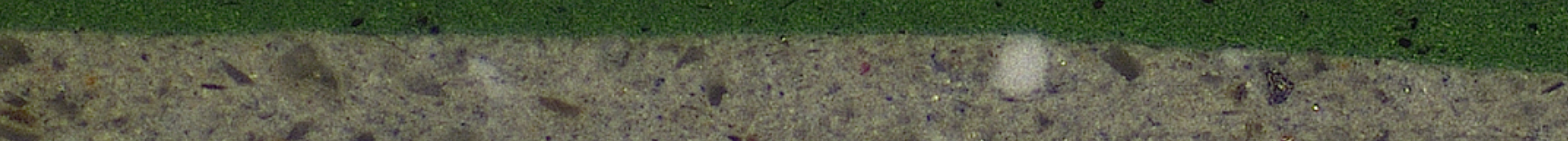

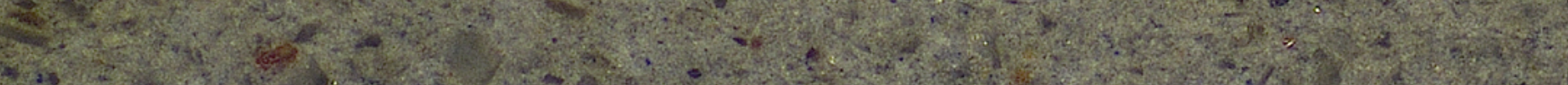

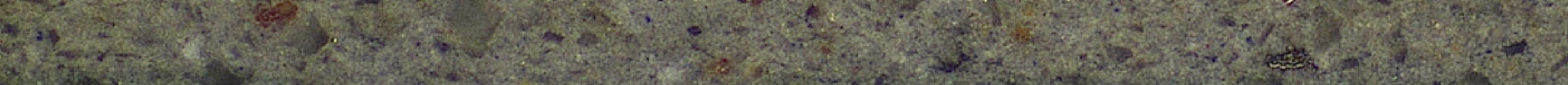

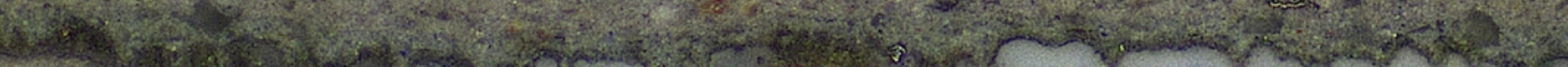

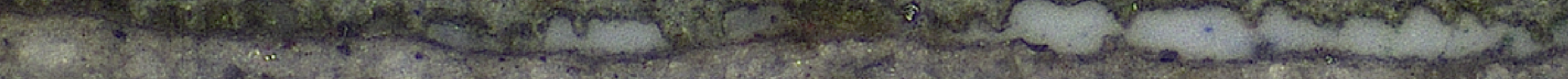
(2)

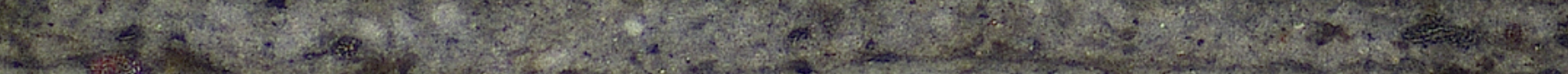

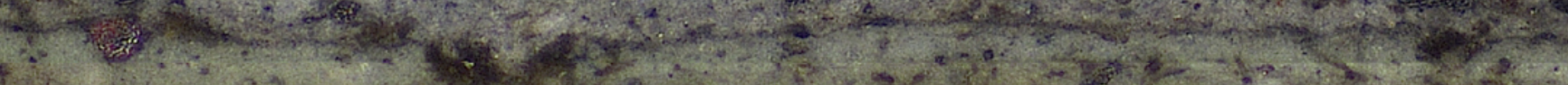

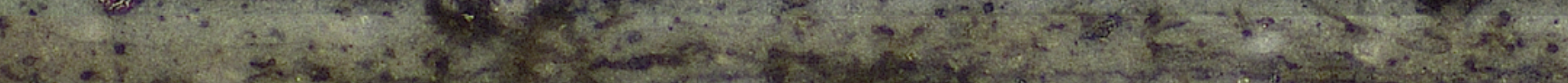
W.

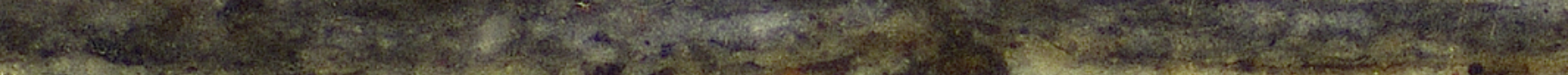

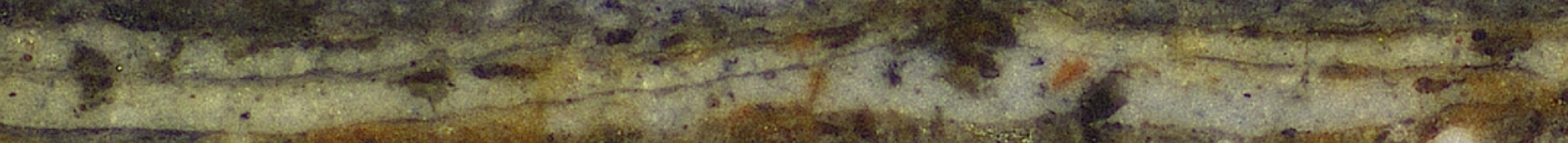

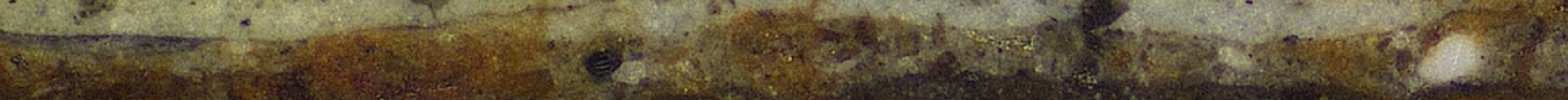




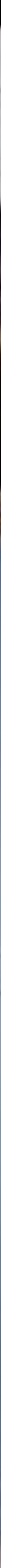




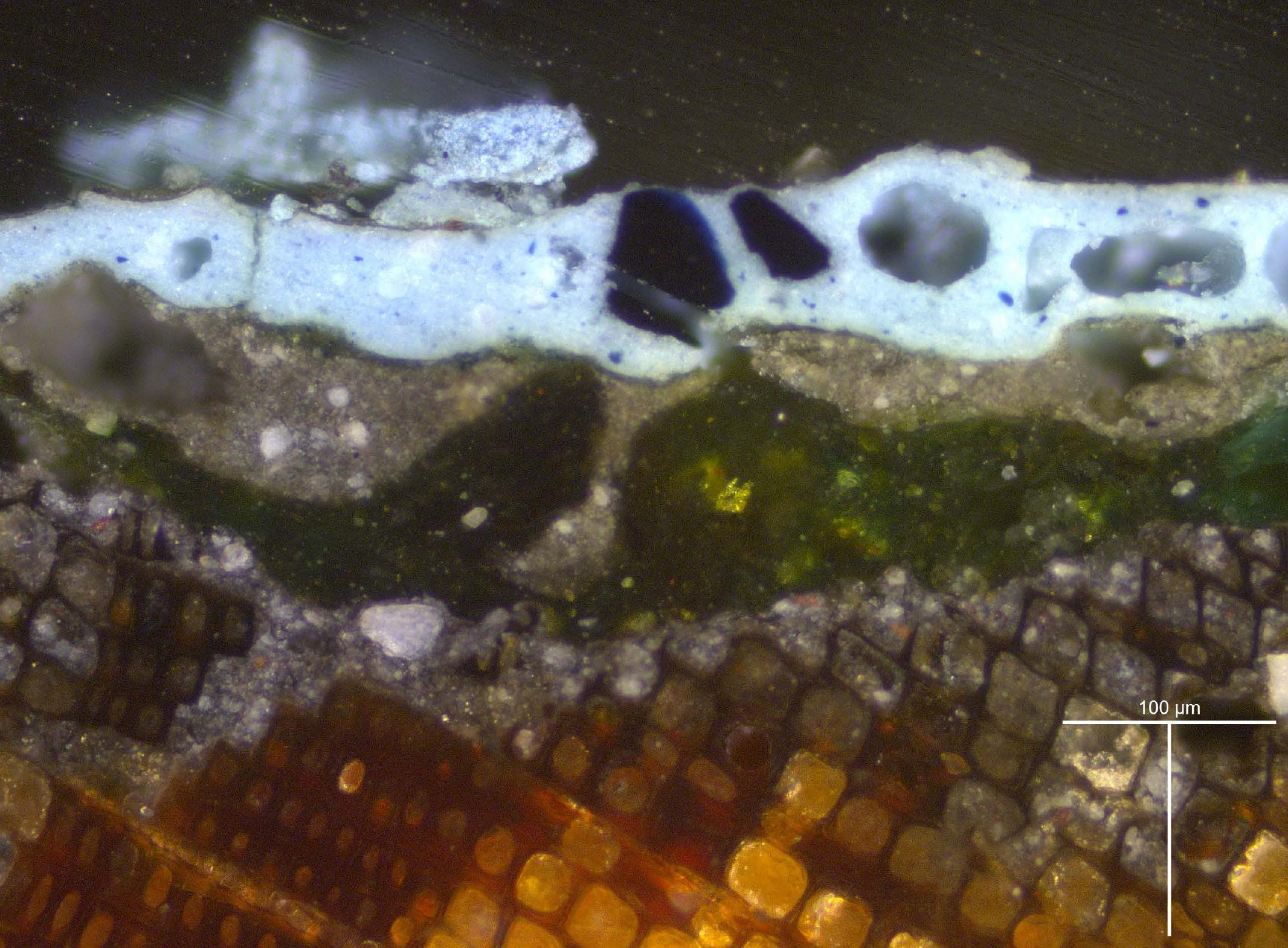





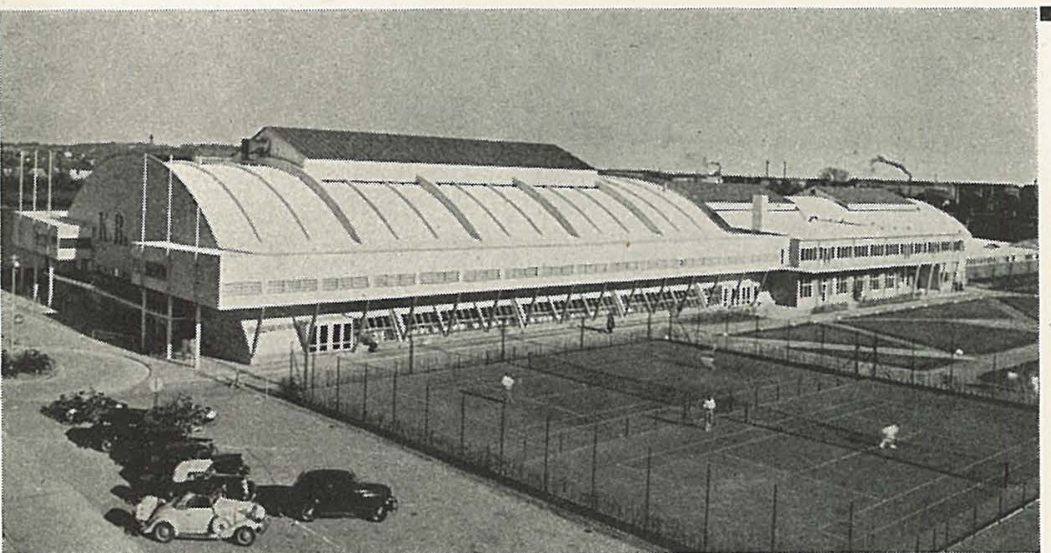

K.B.'s nye, imponerende Sportshaller paa Peter Bangsvej 169 malet med "Creconto".

\section{CRECONTO}

CEMENTMALING TIL FAÇADEARBEJDE

\section{Successen fortscettes}

Det er stadig "Creconto", der er den foretrukne Cementmaling.

K. B.'s nye imponerende Sportshaller blev ogsaa behandlet med "Crecontow. - For hver Dag, der gaar, forlanger flere og flere Arkitekter "Crecontou anvendt til alle Slags Façader - ikke blot til udvendig Brug, ogsaa til indvendig Udsmykning, f. Eks. i Hospitaler, Skoler og Svømmehaller, hvor hyppige Afvaskninger er nødvendige for den daglige Renligholdelse, er "Creconto" særdeles velegnet. Se venligst vore Annoncesider, Side 353 og 358 i H.F. B., hvor udførlige tekniske Oplysninger og Farvekort forefindes.

\section{S. DYRUP ${ }_{2} C_{0 . \frac{A}{5}}$} KØBENHAVN - BRH. 


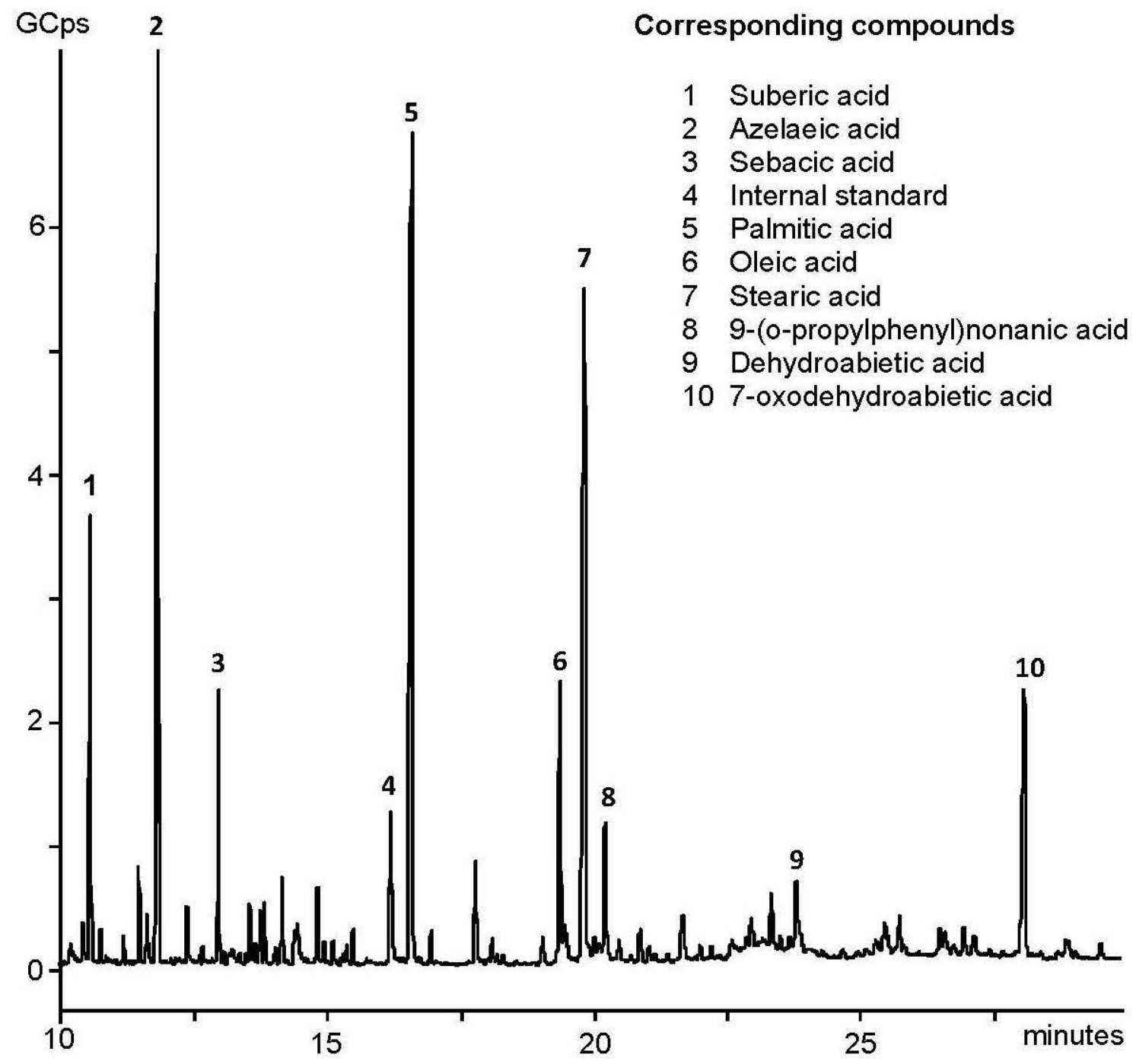

